\title{
P Uptake and Solubility, Growth Characteristics and the Yield of Maize (Zea mays L.) Due to Phosphorhizobacteria and Organic Fertilizers in Acid Soil
}

\author{
F. H. Khumairah ${ }^{1 * 2}$, A. Jingga ${ }^{3}$, B. N. Fitriatin ${ }^{2}$ and T. Simarmata ${ }^{2}$ \\ Date Received: 15 th January 2020 / Date Accepted: $13^{\text {th }}$ May 2020
}

\begin{abstract}
Purpose : The use of phosphorhizobacteria and organic fertilizers can increase the P uptake and solubility as well as promote the growth and yield of maize in acid soil. The objective of the study was to evaluate of $P$ fertilization efficiency by adding phosphorhizobacteria and organic fertilizers and to investigate its influence in the growth and yield of maize.

Research Method : The experiment was conducted at the experimental field of Center for Horticulture Seed and Plant Variety Development, West Java and Soil Biology Laboratory at the Department of Soil Science, Faculty of Agriculture, Universitas Padjadjaran. The factors of the experiment were: phosphorhizobacteria and organic fertilizers (control, phosphorhizobacteria $10^{7} \mathrm{cfu} / \mathrm{mL}$, organic fertilizers 5 ton ha ${ }^{-1}$, combinations of phosphorhizobacteria $10^{7}$ cfu/ $m L+$ organic fertilizers 5 ton ha-1) and the level of inorganic P fertilization (0, 200, 180, 160, and $140 \mathrm{~kg} P \mathrm{ha}$ ) arranged as randomized block design factorial, consisting of 20 treatments and 3 replications.
\end{abstract}

Findings : The results showed that application of phosphorhizobacteria $10^{7} \mathrm{cfu} / \mathrm{mL}$ can increase P solubility up to $21.13 \mathrm{ppm}$. The interactions between phosphorhizobacteria $10^{7} \mathrm{cfu} / \mathrm{mL}$ and organic fertilizers 5 ton ha ${ }^{-1}$ with $180 \mathrm{~kg}$ inorganic $P$ ha $^{-1}$ were capable to increase maize plant height by $183.07 \mathrm{~cm}$ which were measured at 14 weeks after planting. Applications of organic fertilizers 5 ton hal and dosage of inorganic P fertilizers $160 \mathrm{~kg} \mathrm{ha}^{-1}$ can escalate agronomic effectiveness up to $29.20 \%$.

Limitations : Limited availability of historical data was a constraint during the study and that was avoided using data for a base year.

Originality / Value : It is better to conduct a study on nitrogen and potassium rhizobacteria and organic fertilizer in order to find out nitrogen and potassium fertilization efficiency for maize in acid soil because these evidence are useful to the farmer, trader and planners.

Keywords: phosphorhizobacteria, organic fertilizer, maize, acid soil

\section{INTRODUCTION}

More than $30 \%$ of the world's total land area is acid soil, and $50 \%$ of the potential arable lands are acidic (Basak et al., 2016). Soil acidity can inhibit crop growth and reduce crop yields because of deficiencies of $\mathrm{P}, \mathrm{Mo}, \mathrm{Ca}$, and $\mathrm{Mg}$ in soils and aluminum (Al) and manganese (Mn) toxicity to plants (Shi et al., 2017). In acid soils such as Ultisols, available $\mathrm{P}$ are mainly fixed by aluminum and iron-free oxides and hydroxides, which limit P availability (Collavino et al., 2010).

The element $\mathrm{P}$ is essentially needed by maize in order to store and transport energy to the whole body of the plant. Moreover, $\mathrm{P}$ is used for cell division, formation of seeds, and to strengthen roots and stems of maize (Whitelaw, 2000). When deficiency of $\mathrm{P}$ in maize cultivation occurs, the

\footnotetext{
Department of Agrotechnology, Faculty of Agriculture, Bandung Raya University, West Java, Indonesia

fiqriahhanum@unbar.ac.id

2 Department of Soil Science, Faculty of Agriculture, Universitas Padjadjaran, West Java, Indonesia

3 Food Crops and Horticulture Office, West Java Province, Indonesia
}

(1) ORCID http://orcid.org/0000-0002-3264-8333

\section{(c) (i) (2)(2)}


growth and yield of maize will be inhibited. One of the actions that can be carried out by farmers to respond to this problem is the use of inorganic $\mathrm{P}$ fertilizer on a large scale. However, inorganic fertilizers as subsidized non-renewable resources in Indonesia are currently decreasing while the price is increasing. This situation encourages farmers to look for other less complicated and less expensive alternatives for their cultivation techniques (Anwar et al., 2011).

On the other hand, the excessive use of inorganic fertilizers gives a significant effect on land degradation, environmental problems, and yield losses (Simarmata et al., 2016). An abundance of renewable natural resources, such as soil microbes, can be used as biofertilizers, which have the ability to mobilize, facilitate, and increase the availability of nutrients from non-available forms to available ones through biological processes (Simarmata, 2013). The locally available organic fertilizers such as composted chicken manure, municipal waste compost, and coconut-shell biochar can be used to remediate the soil health, increase the efficiency of fertilizers, and crop productivity as well (Simarmata et al., 2016).

Phosphate Solubilizing Bacteria is the primary agent in phosphorhizobacteria biofertilizers which is capable of solubilizing unavailable form of P nutrient into available form to be absorbed by plants (Saparatka, 2003). Phosphorhizobacteria can improve the efficiency of $\mathrm{P}$ fertilization by increasing $\mathrm{P}$ solubility in soil and $\mathrm{P}$ uptake by plants. The ability of phosphorhizobacteria varies greatly depending on the type of microbes, adaptability, and the ability to produce organic acids and phosphatase enzymes (Whitelaw, 2000). In maize, the application of phosphorhizobacteria can increase $\mathrm{P}$ solubility in Ultisols and concentration P in maize plant as well as growth and yield of maize (Fitriatin et al., 2014). Furthermore, inorganic P fertilizers dosage can be reduced up to $50 \%$ (Fitriatin et al., 2015).

The use of organic fertilizers can also improve growth characteristics and the yield of maize.
Organic fertilizers are soil enhancing materials derived from organic materials that can improve soil properties, either physical, chemical, or biological. Organic fertilizers are intended to increase soil fertility, as a source of nutrients, a binding agent or cation-absorbing agent, and a means of reducing soil acidity (Purba, 2015). Composted chicken manure, municipal waste compost, and coconut shell biochar are organic fertilizers. Composted chicken manure has a high nutrient content, namely nitrogen, phosphorus, potassium, calcium, magnesium and sulfur. Composted chicken manure can increase the soil $\mathrm{C} / \mathrm{N}$ ratio and have higher $\mathrm{N}$ and $\mathrm{P}$ contents than other composted animal manure (Sihite et al., 2016). Municipal waste compost applied with inorganic fertilizers is also able to provide the same results with $100 \%$ inorganic fertilizers application (Lestari et al., 2010). The addition of biochar to the soil increases the availability of $\mathrm{K}$ and $\mathrm{P}$, and the total $\mathrm{N}$ which ultimately increases yields can reduce the risk of leaching especially potassium and $\mathrm{N}^{-\mathrm{NH}_{4}}$ (Graber et al., 2017).

Therefore, theapplication of phosphorhizobacteria and organic fertilizers is expected to increase phosphate fertilization efficiency and maize (Zea mays L.) productivity by improving $\mathrm{P}$ uptake and solubility, growth characteristics and yield due to biological activity contained in phosphorhizobacteria, and organic materials in organic fertilizers.

\section{MATERIALS AND METHODS}

\section{Site description and experimental design}

The study was carried out in the experimental field of the Center for Horticulture Seed and Plant Variety Development, West Java, Indonesia from October 2017 until March 2018. The soil was an Ultisol, and soil texture was silty clay. The soil was categorized as acid soil since soil $\mathrm{pH}$ was 5.55. The results of soil physical and chemical analysis are presented in Table 01. 
Table 01: Soil physical and chemical properties

\begin{tabular}{lccccccccccc}
\hline $\mathrm{pH}$ & $\begin{array}{c}\mathrm{C}-\mathrm{org} \\
(\%)\end{array}$ & $\mathrm{C} / \mathrm{N}$ & $\mathrm{N}(\%)$ & $\mathrm{P}(\mathrm{ppm})$ & $\begin{array}{c}\mathrm{K} \\
(\mathrm{mg} .100 \\
\left.\mathrm{g}^{-1}\right)\end{array}$ & $\begin{array}{c}\mathrm{Fe} \\
(\mathrm{ppm})\end{array}$ & $\begin{array}{c}\mathrm{Mn} \\
(\mathrm{ppm})\end{array}$ & $\begin{array}{c}\mathrm{CEC} \\
(\mathrm{cmol} . \\
\left.\mathrm{kg}^{-1}\right)\end{array}$ & $\begin{array}{c}\text { Sand } \\
(\%)\end{array}$ & Silt (\%) & $\begin{array}{c}\text { Clay } \\
(\%)\end{array}$ \\
\hline 5.55 & 1.58 & 12 & 0.13 & 19.24 & 26.09 & 6.39 & 2.68 & 13.88 & 6 & 47 & 47 \\
\hline
\end{tabular}

The experimental design used in this study was randomized block design factorial that consisted of two factors with three replications. The first factor was an application of phosphorhizobacteria and organic fertilizers, i.e. without phosphorhizobacteria $10^{7} \mathrm{cfu} / \mathrm{mL}$ and/or organic fertilizers 5 ton $\mathrm{ha}^{-1}$ (control), phosphorhizobacteria $10^{7} \mathrm{cfu} / \mathrm{mL}$, organic fertilizers 5 ton $\mathrm{ha}^{-1}$, and combinations of phosphorhizobacteria $10^{7} \mathrm{cfu} / \mathrm{mL}+$ organic fertilizers 5 ton $\mathrm{ha}^{-1}$. The second factor was the level of inorganic $\mathrm{P}$ fertilization that consisted of five levels ie. $0,200,180,160$, and $140 \mathrm{~kg} \mathrm{P} \mathrm{ha}^{-1}$.

Soil tillage was carried out before planting as deep as $15-20 \mathrm{~cm}$. The size of the experimental plot was 1.6-2,.1 m with a spacing of $25 \times 75$ $\mathrm{cm}$. Seeds used were BISI 2 hybrid planted in planting holes made using torches with a depth

of about $5 \mathrm{~cm}$. Phosphorhizobacteria and organic fertilizers were used as a planting hole cover. Inorganic N, P, and $\mathrm{K}$ fertilizers were applied in the form of urea, superphosphate-36 (SP36 ) and potassium chloride $(\mathrm{KCl})$, respectively. Fertilization of urea and $\mathrm{KCl}$ was given as much as $350 \mathrm{~kg}$ and $100 \mathrm{~kg} \mathrm{ha}^{-1}$ while SP-36 was given according to treatment. Urea was given in three stages, namely at the the beginning of planting as well as 4 and 5 weeks after planting (WAP). While $\mathrm{KCl}$ was given in two stages, namely, at the beginning of planting and 5 WAP, SP-36 is given entirely at the beginning of planting. Inorganic fertilizers are placed in a hole about 5 $\mathrm{cm}$ from the seed hole.

\section{Phosphorhizobacteria and organic fertilizers preparation}

The bacterial strains used as phosphorizobacteria were obtained from previous screening activities from several districts in West Java. Isolation, characterization, and selection were carried out in Soil Biology Laboratory at the Department of Soil Science, Faculty of Agriculture, Universitas Padjadjaran. Isolates used as consortium consisted of Enterobacter ludwigii, Bulkholderia vietnamiensis, and Citrobacter amalonaticus. Inoculants were propagated in liquid Pikovskaya medium up to a density of $10^{7} \mathrm{cfu} \mathrm{m}^{-1}$, then mixed with the carrier consisting of $50 \%$ peat + $20 \%$ chicken manure compost $+20 \%$ coconut shell biochar $+10 \%$ additive at a ratio of $1: 3$ (inoculants : carrier). A mixture of inoculants and carriers, known as solid phosphorhizobacteria fertilizers are then wrapped in aluminum foil. Organic fertilizers are used in the form of a mixture of chicken manure compost, municipal waste compost, and coconut shell biochar at a ratio of $25 \%: 25 \%: 50 \%$.

\section{P Uptake and Solubility Determination}

P uptake analysis used the wet destruction method (Indonesian Soil Research Center, 2009). Plant samples were air-dried, and then placed in an oven at $75^{\circ} \mathrm{C}$ for 48 hours. Then, the sample was removed and ground until smooth with a blender. The amount of 0.25 grams of a mashed sample was put into a $25 \mathrm{ml} \mathrm{Kjeldahl} \mathrm{flask,} \mathrm{adding} 5 \mathrm{ml}$ of $\mathrm{HNO}_{3} .0 .5 \mathrm{ml}$ of $\mathrm{HClO}_{4}$ into the flask, and then it was shaken gently so that all samples were moistened, then left overnight. A flask was heated in a smoke chamber with low heat, then slowly fired to a temperature of $350^{\circ} \mathrm{C}$. Destruction was complete when white steam came out and a clear extract (about 4 hours) was obtained. The amount of $50 \mathrm{ml}$ of distilled water was added and shaken briefly and then transferred to the distillation flask. As a comparison, we made a blank sample without using plant samples. The amount of $1 \mathrm{ml}$ of extract and standard row were pipetted into the test tube and $9 \mathrm{ml}$ of $\mathrm{La} 0.25 \%$ solution was added and shaken until homogeneous. P uptake was measured by a spectrophotometer. 
The P solubility analysis used the Bray method (Indonesian Soil Research Center, 2009). The amount of 25 grams of soil sample and $25 \mathrm{ml}$ Bray extractor was added into test tube and shaken for 5 minutes. After that, $2 \mathrm{ml}$ clear extract was pipetted into another test tube. Each sample and standard series were added with a 10 $\mathrm{ml}$ phosphate dye reagent then shaken and left for 30 minutes. The absorbance was measured with a spectrophotometer at a wavelength of $693 \mathrm{~nm}$.

\section{Growth Characteristics and The Yield of Maize Determination}

Growth characteristics were represented in plant height. Sample plants were measured at the harvesting period (14 weeks after planting) from the base of the stem to the tip of the leaf or shoot. The yield of maize was represented in relative agronomic effectiveness (RAE) value. The RAE of each treatment was calculated using the equation (Barreto et al., 2018):

$$
\operatorname{RAE}(\%)=\left[\left(\mathrm{P}_{i}-\mathrm{P}_{0}\right) / \mathrm{P}_{a}\right] \times 100
$$

Where;

$\mathrm{P}_{i}=$ dry shell weight in treatments with added inorganic $\mathrm{P}$ fertilizers $\left(\mathrm{kg} \mathrm{ha}^{-1}\right)$

$\mathrm{P}_{0}=$ dry shell weight without addition of inorganic $P$ fertilizers (control)

$\mathrm{P}_{a}=$ amount of inorganic $\mathrm{P}$ fertilizers given in each treatment $\left(\mathrm{kg} \mathrm{ha}^{-1}\right)$.

\section{Statistical Analysis}

All data were statistically analyzed using oneway analysis of variance (ANOVA) and the difference between treatments was tested by Duncan's multiple range test at $p \leq 0.05$. All the statistical tests were performed using the SPSS 16.0 software.

\section{RESULTS AND DISCUSSION}

\section{P Uptake and Solubility}

The effect of phosphorhizobacteria and organic fertilizers in several doses of inorganic $P$ fertilizers on $\mathrm{P}$ uptake and solubility was summerized in Table 02. Based on the analysis of variance, it can be seen that there was no interaction between phosphorhizobacteria and organic fertilizers treatment factors with several doses of inorganic $\mathrm{P}$ fertilizers in $\mathrm{P}$ uptake by plants and soil $\mathrm{P}$ solubility during the experiment. Yet, the independent effect was seen in the inoculation of phosphorhizobacteria $10^{7} \mathrm{cfu} / \mathrm{mL}$, which has had the highest $\mathrm{P}$ solubility significantly compared to combinations of phosphorhizobacteria + organic fertilizers treatment, but it was not significantly different from control and organic fertilizers 5 ton $\mathrm{ha}^{-1}$ treatment. This is presumably due to optimum phosphorhizobacteria performance in dissolving $\mathrm{P}$ or providing available $\mathrm{P}$ for plants.

Table 02: P Uptake and Solubility due to Phosphorhizobacteria and Organic Fertilizers

\begin{tabular}{|c|c|c|}
\hline Treatments & $\begin{array}{c}\text { P uptake }(\mathrm{g} / \\
\text { plant })\end{array}$ & $\begin{array}{c}\text { P Solubility } \\
\text { (ppm) }\end{array}$ \\
\hline \multicolumn{3}{|l|}{ Phosphorhizobacteria and Organic Fertlizers (B) } \\
\hline $\mathrm{b}_{0}=$ Without phosphorhizobacteria and organic fertilizers (control) & 3.50 & $19.20^{\mathrm{b}}$ \\
\hline $\mathrm{b}_{1}=$ Phosphorhizobacteria $10^{7} \mathrm{cfu} / \mathrm{mL}$ & 3.01 & $21.13^{\mathrm{b}}$ \\
\hline $\mathrm{b}_{2}=$ Organic fertilizers 5 ton $\mathrm{ha}^{-1}$ & 3.42 & $18.71^{\mathrm{b}}$ \\
\hline $\mathrm{b}_{3}=$ Phosphorhizobacteria $10^{7} \mathrm{cfu} / \mathrm{mL}+$ organic fertilizers 5 ton $\mathrm{ha}^{-1}$ & 3.44 & $14.54^{\mathrm{a}}$ \\
\hline \multicolumn{3}{|l|}{ Dosage of inorganic $\mathrm{P}$ fertilizers $(\mathrm{P})$} \\
\hline $\mathrm{p}_{0}=0 \mathrm{~kg} \mathrm{Pha}^{-1}$ & 3.57 & 17.24 \\
\hline $\mathrm{p}_{1}=200 \mathrm{~kg} \mathrm{Pha}{ }^{-1}$ & 3.19 & 18.92 \\
\hline $\mathrm{p}_{2}=180 \mathrm{~kg} \mathrm{Pha}{ }^{-1}$ & 3.29 & 20.17 \\
\hline $\mathrm{p}_{3}=160 \mathrm{~kg} \mathrm{Pha}^{-1}$ & 3.45 & 16.57 \\
\hline $\mathrm{p}_{4}=140 \mathrm{~kg} \mathrm{P} \mathrm{ha}^{-1}$ & 3.21 & 19.07 \\
\hline
\end{tabular}

Treatments with superscripted alphabet showed the significant value $(P<0.05)$. 
According to various research results, adding organic material into fertilizers can retain and supply nutrient availability in the soil and increase phosphate absorption by plants (Carter et al., 2013). The mechanism of phosphate solubilization by organic matter can be through a process of decomposition which produces organic acids to dismiss $\mathrm{C}, \mathrm{Al}$, and $\mathrm{Ca}$ cations in absorbing organic $\mathrm{P}$ (fitine and nucleic) (Afrida et al., 2014), and as a provider of carbon sources to phosphate solubilizing bacteria to dissolve mineralized bound P (Richardson, 2001).

\section{Growth characteristics}

The effect of phosphorhizobacteria and organic fertilizers in plant height showed a higher value at $180 \mathrm{~kg} \mathrm{ha}^{-1} \mathrm{P}$ fertilizers compared to doses of 160 and $140 \mathrm{~kg} \mathrm{ha}^{-1}$ but not significantly different from fertilizers doses of 200 and $0 \mathrm{~kg} \mathrm{ha}^{-1}$. The results indicated that the growth of maize reflected by plant height data was optimal on the use of combination of phosphorhizobacteria + organic fertilizers at $180 \mathrm{~kg} \mathrm{ha}^{-1}$ which has been processed by Duncan's multiple range test at 5\% real level.

Organic matter is a source of energy for soil macro- and microorganisms. The addition of organic matter in the soil will increase microbiological activity and population, especially those related to the decomposition and mineralization of organic matter (Stevenson, 1986). The provision of organic material is very important in improving the physical, chemical and biological properties of the soil so that plants that grow on it can develop properly (Sanchez, 1992).

\section{Agronomic Effectiveness}

Agronomic effectiveness was carried out to see the effect of phosphorhizobacteria and organic fertilizers in several doses of inorganic $P$ fertilization on the yield of maize. Based on the results of data analysis it was pointed out that the use of phosphorhizobacteria and organic fertilizers can improve the agronomic effectiveness of maize compared to control maximum up to $29.20 \%$. Observations on the components of maize yield were carried out using dry shell weight, as an illustration of the process of seed filling during the generative phase. The process of seeds cannot be separated from the role of nutrients absorbed by plants. The addition of phosphorus greatly influences the formation of cobs (Tarigan et al., 2007). Phosphorus can enlarge the formation of fruit. In addition, the availability of phosphorus as a form of ATP will ensure the availability of energy for growth characteristics so that the formation of assimilates and transportation to storage can run well. The availability of sufficient nutrients at the time of plant growth and development causes plant metabolic activity to be more active so that the process of cell elongation and differentiation will be better which can ultimately encourage an increase in yield components (Sarief, 1989).

Table 03: $\quad$ Plant Height at 14 WAP due to Phosphorhizobacteria and Organic Fertilizers

\begin{tabular}{|c|c|c|c|c|c|}
\hline \multicolumn{6}{|c|}{ Plant Height $(\mathrm{cm})$} \\
\hline \multirow{2}{*}{ Phosphorhizobacteria and Organic fertilizers } & \multicolumn{5}{|c|}{ Dosage of inorganic P Fertilizers } \\
\hline & $0 \mathrm{~kg} \mathrm{ha}^{-1}$ & $200 \mathrm{~kg} \mathrm{ha}^{-1}$ & $180 \mathrm{~kg} \mathrm{ha}^{-1}$ & $160 \mathrm{~kg} \mathrm{ha}^{-1}$ & $140 \mathrm{~kg} \mathrm{ha}^{-1}$ \\
\hline $\begin{array}{l}\text { Without phosphorhizobacteria and organic } \\
\text { fertilizers (control) }\end{array}$ & $\begin{array}{c}159.50 \mathrm{a} \\
\mathrm{A}\end{array}$ & $\begin{array}{c}170.47 \mathrm{a} \\
\mathrm{A}\end{array}$ & $\begin{array}{c}168.60 \mathrm{a} \\
\mathrm{A}\end{array}$ & $\begin{array}{c}153.70 \mathrm{a} \\
\mathrm{A}\end{array}$ & $\begin{array}{c}160.04 \mathrm{a} \\
\mathrm{A}\end{array}$ \\
\hline Phosphorhizobacteria $10^{7} \mathrm{cfu} / \mathrm{mL}$ & $\begin{array}{c}159.93 \mathrm{a} \\
\mathrm{A}\end{array}$ & $\begin{array}{c}168.53 \mathrm{a} \\
\mathrm{A}\end{array}$ & $\begin{array}{c}168.99 \mathrm{a} \\
\mathrm{A}\end{array}$ & $\begin{array}{c}162.23 \mathrm{a} \\
\mathrm{A}\end{array}$ & $\begin{array}{c}161.97 \mathrm{a} \\
\mathrm{A}\end{array}$ \\
\hline Organic fertilizers 5 ton $\mathrm{ha}^{-1}$ & $\begin{array}{c}167.42 \mathrm{a} \\
\mathrm{A}\end{array}$ & $\begin{array}{c}164.47 \mathrm{a} \\
\mathrm{A}\end{array}$ & $\begin{array}{c}171.83 \mathrm{a} \\
\mathrm{A}\end{array}$ & $\begin{array}{c}170.47 \mathrm{a} \\
\mathrm{A}\end{array}$ & $\begin{array}{c}168.53 \mathrm{a} \\
\mathrm{A}\end{array}$ \\
\hline $\begin{array}{l}\text { Phosphorhizobacteria } 10^{7} \mathrm{cfu} / \mathrm{mL}+\text { organic } \\
\text { fertilizers } 5 \text { ton } \mathrm{ha}^{-1}\end{array}$ & $\begin{array}{c}166.40 \mathrm{a} \\
\mathrm{ABC}\end{array}$ & $\begin{array}{l}174.80 \mathrm{a} \\
\mathrm{BC}\end{array}$ & $\begin{array}{l}183.07 \mathrm{a} \\
\mathrm{C}\end{array}$ & $\begin{array}{c}158.77 \mathrm{a} \\
\mathrm{AB}\end{array}$ & $\begin{array}{c}153.40 \mathrm{a} \\
\mathrm{A}\end{array}$ \\
\hline
\end{tabular}

Figures followed by the same notation are not significantly different based on Duncan Multiple Range Test at 5\% real level. Small letters are read vertically, uppercase letters are read horizontally. 


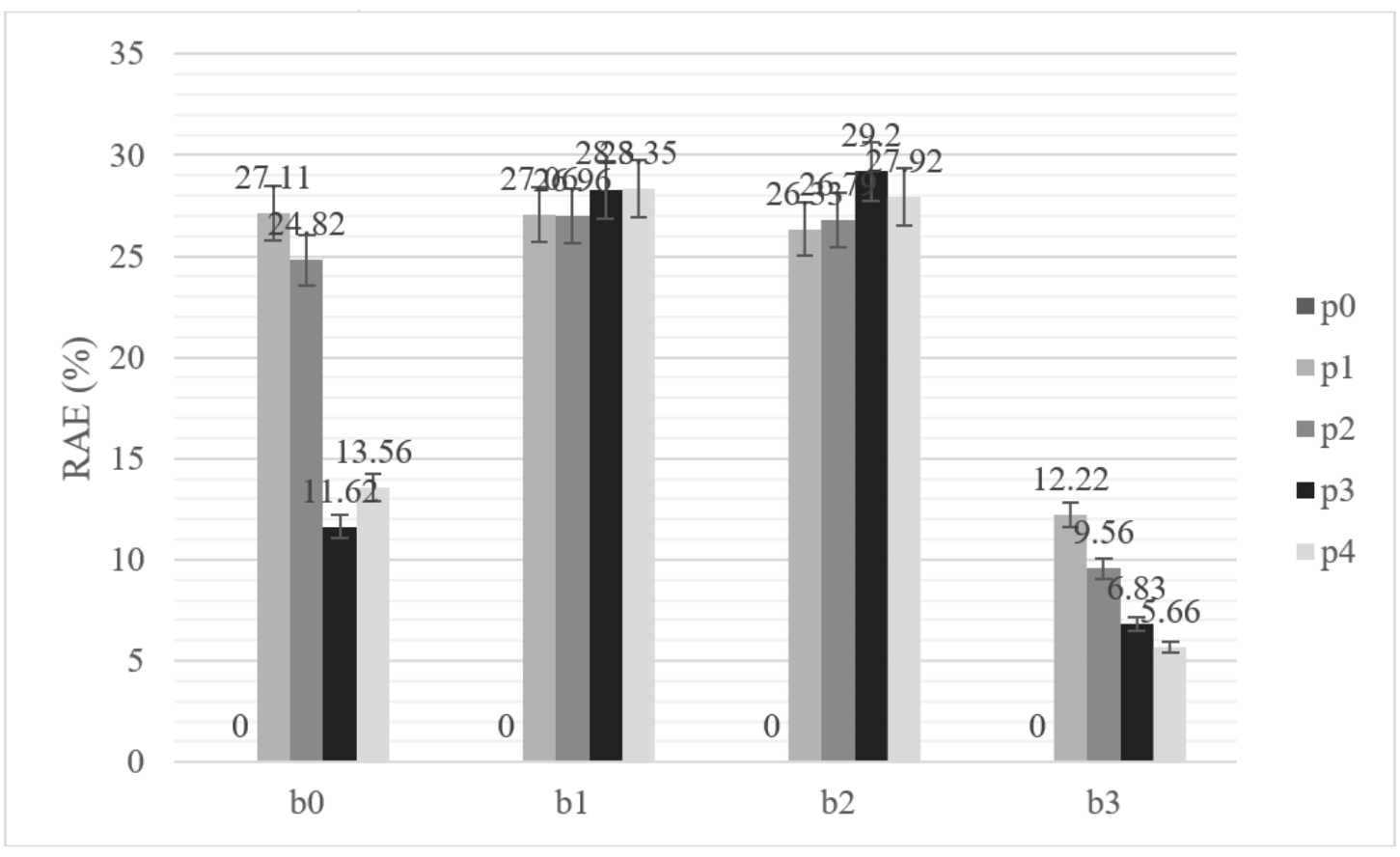

Figure 01: Relative Agronomic Effectiveness of phosphorhizobacteria and organic fertilizers in maize cultivation with several doses of inorganic $P$ fertilizers. Without phosphorhizobacteria and organic fertilizers (b0), Phosphorhizobacteria $107 \mathrm{cfu} / \mathrm{mL}$ (b1), Organic fertilizers 5 ton ha-1 (b2), Phosphorhizobacteria $107 \mathrm{cfu} / \mathrm{mL}+$ organic fertilizers 5 ton ha-1 (b3), inorganic P Fertilizers 0 kg ha-1 (p0), 200 kg ha-1 (p1), 180 kg ha-1 (p2), 160 kg ha-1 (p3), 140 kg ha-1 (p4).

\section{CONCLUSIONS}

Applications of phosphorhizobacteria $10 \mathrm{cfu} /$ $\mathrm{mL}$ can increase $\mathrm{P}$ solubility up to $21.13 \mathrm{ppm}$. Interactions between phosphorhizobacteria $10^{7}$ $\mathrm{cfu} / \mathrm{mL}$ and organic fertilizers 5 ton $\mathrm{ha}^{-1}$ capable to support growth characteristics up to $183.07 \mathrm{~cm}$ and were optimum to reduce the use of inorganic $\mathrm{P}$ fertilizers from $200 \mathrm{~kg} \mathrm{ha}^{-1}$ to $180 \mathrm{~kg} \mathrm{ha}^{-1}$. The use of organic fertilizers 5 ton $\mathrm{ha}^{-1}$ and dosage of inorganic $\mathrm{P}$ fertilizers $160 \mathrm{~kg} \mathrm{ha}^{-1}$ can escalate agronomic effectiveness up to $29.20 \%$.

\section{Data Availability Statement}

The datasets generated during and/or analysed during the current study are available from the corresponding author on reasonable request.

\section{ACKNOWLEDGMENT}

We would like to give our biggest appreciation to Universitas Padjadjaran for funding this research through ALG (Academic Leadership Grant).

\section{REFERENCES}

Afrida, E., A. Rauf. H. Hanum., dan D. Harnowo. 2014. Efek Residu Pupuk Organik dan Penambahan Pupuk Anorganik terhadap Sifat Kimia dan Biologi Tanah pada Lahan Sawah Tadah Hujan. Proceeding Seminar Nasional HITI Komda Aceh. DOI: https://doi.org/10.22373/biotik.v2i1.236

Anwar, Ea Kosman and Subowo Gitosuwondo. 2011. Effectiveness of Commercial Biofertilizers on Fertilization Efficiency in Ultisols for the Growth and Yield of Caisim. J Trop Soils, Vol. 16, No. 3: 191-199. DOI: https://doi.org/10.5400/jts.2011.16.3.191

Basak, B. B and D.R. Biswas. 2016. Potentiality of Indian rock phosphate as liming material in acid soil. Geoderma 263 : 104-109. DOI: https://doi.org/10.1016/j.geoderma.2015.09.016 
Barreto, M S C, Edson Marcio Mattiello, Wedisson Oliveira Santos, Leonidas Carrijo Azevedo Melo, Leonardus Vergütz, and Roberto Ferreira Novais. 2018. Agronomic efficiency of phosphate fertilizers produced by the re-use of a metallurgical acid residue. Journal of Environmental Management 208 : 1 - 7. DOI: https://doi.org/10.1016/j.jenvman.2017.11.075

Carter, S., S. Shackley., S. Sohi., T. B. Suy., and S. Haefele. 2013. The Impact of Biochar Application on Soil Properties and Plant Growth of Pot Grown Lettuce (Letuca sativa) and Cabbage (Brassica chinensis). Journal Agronomy 3; 440-418. DOI: https://doi.org/10.3390/agronomy3020404

Collavino, Mónica M., Pedro A. Sansberro, Luis A. Mroginski, and O. Mario Aguilar. 2010. Comparison of In Vitro Solubilization Activity of Diverse Phosphate-Solubilizing Bacteria Native to Acid Soil and Their Ability to Promote Phaseolus vulgaris Growth. Biol Fertil Soils 46 : 727-738. DOI: https://doi.org/10.1007/s00374-010-0480-х

Fitriatin, B.N., A. Yuniarti, T. Turmuktini, dan F.K. Ruswandi. 2014. The Effect of Phosphate Solubilizing Microbe Producing Growth Regulators on Soil Phosphate, Growth and Yield Of Maize and Fertilizers Efficiency on Ultisol. Eurasian Journal of Science 3: 101-107. DOI: https://doi.org/10.18393/ejss.34313

Fitriatin, B.N., Mayang Agustina dan Reginawanti Hindersah. 2015. Populasi Bakteri Pelarut Fosfat, P-Potensial Dan Hasil Jagung Yang Dipengaruhi Oleh Aplikasi MPF Pada Ultisols Jatinangor. Agrologia, Vol. 6, No.2, Oktober 2017, Hal. 75-83. DOI: https://doi.org/10.30598/a.v6i2.171

Graber, E. R., Singh, B., Hanley, K., and Lehmann, J (eds). 2017. Biochar: A Guide to Analytical Methods.

Indonesian Soil Research Center. 2009. Jurnal Teknis Analisis Kimia Tanah, Tanaman, Air, dan Pupuk. ISBN 978-602-8039-21-5

Lestari, A.P., Sarman S., and E. Indraswari. 2010. Substitusi Pupuk Anorganik dengan Kompos Sampah Kota Tanaman Jagung Manis (Zea mays saccharata Sturt). Jurnal Penelitian Universitas Jambi seri Sains 12 (2): 1-6. DOI: https://doi.org/10.22216/jbbt.v2i1.2763

Purba, Resmayeti. 2015. Study of Ameliorant Utilization on Dry Land in Increasing Yield and Profits of Soy Farming. Proceeding National Seminar Indonesia Biodiversity Society 1 (6) : 1483-1486

Richardson.A.E. 2001. Prospect for using soil microorganisms to improve the a quisition of phosphorus by plants. Aust. J. Plant Physiol. 58: 797- 906.

Sanchez, P.A. 1992. Sifat dan Pengelolaan Tanah Tropika. Institut Teknologi Bandung. Bandung.

Saparatka, N. 2003. Phosphatase activities (ACP, ALP) in Agroecosystem Soils. Doctoral thesis. Swedish University of Agricultural Sciences. Uppsala.

Sarief, E. S. 1989. Kesuburan dan Pemupukan Tanah Pertanian. Pustaka Buana. Bandung. 150 hlm. Hal 45-47.

Sihite, E.A., M.M.B. Damanik, and M. Sembiring. 2016. Changes in Some Soil Chemical Properties, P Uptake, and Growth of Maize Plants in Inceptisol Kwala Soil Due to the Provision of Chicken Manure and Some Other Sources. Journal Agroekoteknologi 4 (3) : 2082-2090

Simarmata, T., Hersanti, Tien Turmuktini, Betty N. Fitriatin, Mieke R. Setiawati, and Purwanto. 2016. Application of Bioameliorant and Biofertilizers to Increase the Soil Health and Rice Productivity. HAYATI Journal of Biosciences 23: 181-184. 
Simarmata, T. 2013. Tropical Bioresources to Support Biofertilizers Industry and Sustainable Agriculture in Indonesia. International Seminar on Tropical Bio-resources for Sustainable Bioindustry; from Basic Research to Industry. 30- 31st October 2013 in ITB. Bandung. Indonesia. DOI: https://doi.org/10.1016/j.hjb.2017.01.001

Shi, Ren-yong., Zhi-neng Hong, Jiu-yu Li, Jun Jiang, M. Abdulaha-Al Baquy, Ren-kou Xu, and Wei Qian. 2017. Mechanisms for Increasing the $\mathrm{pH}$ Buffering Capacity of an Acidic Ultisol by Crop Residue-Derived Biochars. J. Agric. Food Chem. 65 : 8111-8119. DOI: https://doi. org/10.1021/acs.jafc. 7 b02266

Stevenson, F. J., 1986. Cycles of Soil Carbon, Nitrogen, Phosphorus, Sulfur, Micronutrient. A WileyInetrscience Publication John Wiley \& Sons.

Tarigan, T., Sudiarso dan Respatijarti. 2007. Studi tentang Dosis dan Macam Pupuk Organik pada Pertumbuhan dan Hasil Tanaman Jagung Manis (Zea mays saccharata Sturt.). Universitas Brawijaya. DOI: https://doi.org/10.31943/agrowiralodra.v1i1.143

Whitelaw. 2000. Growth promotion of plants inoculated wth phosphate solubilizing fungi. Adv. Agron 69 : 99-151. DOI: https://doi.org/10.1016/s0065-2113(08)60948-7 